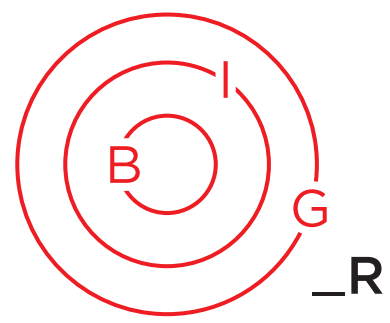

POETRY

SPECIAL ISSUE

\title{
confined body
}

\author{
Natasha Sardzoska
}

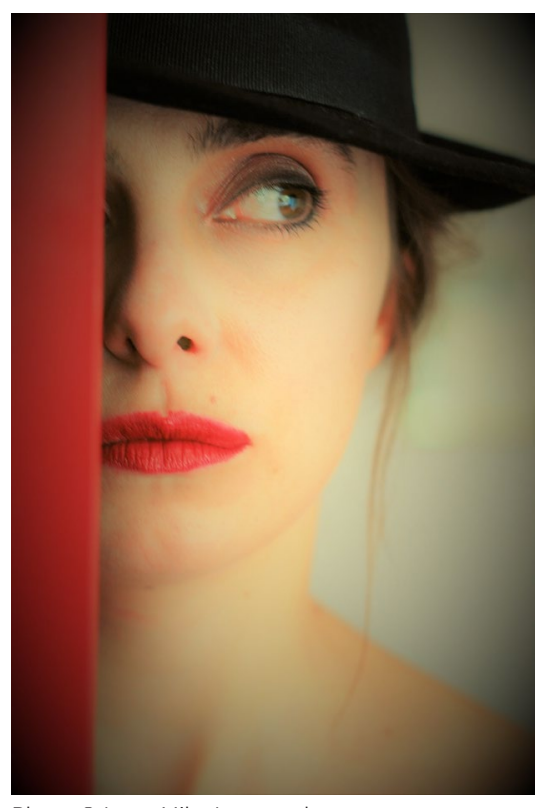

I wrote CONFINED BODY during the confinement. I was a prohibited citizen, banned citizen. I had no right to move or to travel. My body has become a frontier. Mobile frontier. The thin and thick membrane barrier between me and the world of contagion. My body was confined. I was observing and watching my body as a fortress and at the same time as an imprisoned organism. Recluded, cut off, isolated, limited, forbidden, confined, in quarantine, in silence, in immobility. I wrote this poem observing my confined body and everything that came out and that I let in inside my body. It was a traumatic experience.

Natasha Sardzoska (1979), poet, writer, essayist, polyglot translator and interpreter was born in Skopje in Macedonia. She holds a PhD in anthropology from the Eberhard Karls University of Tübingen, Sorbonne Nouvelle in Paris and University of Bergamo. She has published the poetry books Blue Room, Skin, He pulled me with invisible string, Living Water, Coccyx, essays, academic papers and short stories. Her books are published books in the USA and Italy and her selected poems are translated in international literary reviews in more than 20 world languages. Her poem Doll on Strings has been published in the International Poetry Anthology against child abuse. She has performed at international poetry festivals among which: Ars Poetica in Bratislava; Words Wide Open in Genova; Scream in Rijeka; in the Revoltella Museum in Trieste; in the Academy of Arts for the Poetry Festival of Berlin; at the Sha'ar International Poetry Festival performing with sax, contrabass and contemporary dance in the Yaffa Theatre in Tel Aviv as well as at the biggest poetry festival in the world in Medellin in Columbia.

Email: natasha.sar@gmail.com

Twitter: @NSardzoska

BIG_Review journal homepage: https://journals.uvic.ca/index.php/bigreview Borders in Globalization homepage: https://biglobalization.org/ 


\section{confined body}

this body is not my body

other bodies live inside me

bodies that I call mine

because to me they belong

to me they recall

I do have a pact

with all the microorganisms

inhabiting this body

seeking out for me

burning from within

screaming loud

for they want to get

outside of me

but I will never

give them

a cease-fire

$*$

this body is not my body this body is every day haunted by army and odd red guests

they take what they want they leave what they need this body is nailed by winds they leave as fire defeats from the nostrils they abandon this body empty 
this body is not my body inside this body there are tenants inside this body there are hutches

yet: I hide this body there

I help this body to remain silent while I seek inside the seesaw the girl made of bones and nerves

yes: this body is not my body

it is made of storm of lava and larva and swelter and scepter and sceptic questions which punch me from within from within my tongue is entangled welded behind my teeth convicted by the shooting wall:

they blow away the wheat: then they leave only the sickle inside my throat 